\title{
La luna de Apolo
}

\section{Tania Escobar}

Desde que Apolo era un ratoncito, no más grande que un dedal, estaba fascinado con la luna.

Cada noche cuando el sol se escondía, Apolo se asomaba a su ventana a ver la luna hacer su espectacular apariencia y soñaba con algún día poder estar más cerca de ella.

Apolo compartió su sueño con su mamá y para su cumpleaños recibió un telescopio. Cada vez que Apolo acercaba el telescopio a sus ojos, algo mágico sucedía-la luna se acercaba. Apolo podía ver los cráteres, las sombras y las estrellas que ayudan a la luna a alumbrar la noche. Pero al quitar el telescopio de su ojo, la luna se volvía a alejar y Apolo se preguntaba tristemente por qué la luna no quería estar cerca de él.

Una noche, Apolo decidió confrontar a la luna sobre su lejanía. Al salir de su casa vio una colina. "Ciertamente la altura de la colina me acercará un poco más al cielo. Y entonces, la luna me oirá cuando le pregunte por qué no se quiere acercar a mí", pensó Apolo.

Al llegar a la cima de la colina, Apolo vio un armadillo y le dijo:

- Señor Armadillo, me encanta su casa. ¡Qué afortunado es de tener una casa tan cerca de la luna.

- Bah_respondió el armadillo — solamente soy afortunado en noches como hoy que las nubes cubren su luz molesta. Apolo miró rápidamente hacia arriba y se desalentó al ver que la luna se había escondido detrás de las nubes.

Determinado a saber porqué la luna se había escondido, Apolo corrió hacia la montaña más alta. Al llegar a la cima, Apolo se encontró con un lobo que le aullaba a la luna.

- Señor Lobo, disculpe que lo moleste, pero me gustaría saber ¿qué está haciendo?

-Vengo aquí todas las noches a cantarle a la luna-dijo el lobo.

En ese instante a Apolo se le ocurrió que quizás la razón por la que la luna no le respondía, era porque no estaba hablando su lenguaje. Entonces, respiró profundo y aulló lo más fuerte posible. Muy a su pesar, la luna no le respondió.

Al momento, Apolo pensó que por ser tan pequeño, la luna no lo escuchaba. Desesperado, se subió a la rama más alta del árbol más alto. Allí vio un pájaro volando sobre la rama y le gritó:

— ¡Pájaro! ¡Cómo quisiera ser como tú! Me encantaría tener tus alas para poder volar cerca de la luna. 
Mira cuánto más cerca estás de la luna que yo.

El pájaro voló hacia Apolo, se sentó a la par de él y le dijo:

-Ratoncito, yo he volado grandes alturas y nunca me he podido acercar lo suficiente a la luna, pero te puedo asegurar que se ve igual de bella aquí en la punta de la montaña que abajo, en tu casa en el valle.

Todavía un poco triste por no haber cumplido la misión de su aventura, Apolo empezó su camino de regreso a casa. Se despidió del pájaro, se bajó del árbol y de la montaña, pasó sobre la colina y se encontró con un lago pequeño. Se agachó a tomar agua y para su sorpresa, la luna estaba allí enfrente de él. Apolo no lo podía creer, la luna había escuchado su deseo y había bajado para estar con él.

Al escuchar al ratoncito emocionado, el pájaro bajo de su nido a ver qué pasaba.

— ¡La luna vino a mí!- - le explicó Apolo al pájaro y el pájaro respondió:

- Con un poco de fe, esmero y una mente abierta, no hay límites en las posibilidades para la felicidad. 